\title{
EFFECTS OF FAT TYPE ON THE TEXTURAL PROPERTIES OF CORN PUREE
}

\author{
Hakan Erinç* \\ Dept. of Food Eng., Faculty of Engineering, Niğde Ömer Halisdemir University, Niğde, Turkey
}

Received / Geliş: 25.05.2018; Accepted / Kabul: 15.10.2018 Published online / Online bask1: 20.10.2018

Erinc, H. (2018). Effects of fat type on the textural properties of corn puree. GIDA (2018) 43 (5): 856-864 doi: 10.15237/gida.GD18044

Erinç, H. (2018). Yağ çeşidinin mısır püresinin tekstürel özellikleri üzerine etkileri. GIDA (2018) 43 (5): 856-864 doi: 10.15237/gida.GD18044

\begin{abstract}
In this study, corn flour, milk powder, sugar, emulsifier, and fat (milk fat, palm stearin, sunflower oil and mixture of palm stearin and sunflower oil) were used to produce corn puree. After producing the corn puree, the textural properties of the samples were determined to prepare a formula for a viscoelastic corn puree as a new nutritious product for the food industry. The viscoelastic properties of corn puree samples prepared by various ratios of different fat sources and mix (milk fat, palm stearin, sunflower oil, and a mixture of palm stearin and sunflower oil) were evaluated in the temperature range of 25 to $50^{\circ} \mathrm{C}$ using a texture analyzer. As the amount of fat increased (40\%), the corn puree produced became softer except the sample containing palm stearin, which was found to be harder. As the temperature was reduced, the firmness and work of shear values of purees produced using $10-40 \%$ of fat increased.
\end{abstract}

Keywords: corn, puree, fat, milk fat, palm stearin, sunflower, texture

\section{YAĞ ÇEŞİIINİN MISIR PÜRESİNIN TEKSTÜREL ÖZELLIKKLERİ ÜZERİNE ETKILERİ}

\section{ÖZ}

Bu çalışmada, mısır unu, süt tozu, şeker, emülgatör ve yağ (süt yağı, palm stearin, ayçiçek yağı ve palm stearin ile ayçiçeği yağı karışımı) mısır püresi üretmek için kullanılmıştır. Gıda sanayi için besleyici değeri yüksek viskoelastik özellikte yeni bir ürün ortaya koyabilmek amaciyla misır püresi üretildikten sonra ürünlerin tekstürel özellikleri belirlenmiştir. Farklı yağ kaynakları (süt yağı, palm stearin, ayçiçeği yağı ve palm stearin ile ayçiçeği yağı karışımı) ve farklı yağ oranları kullanılarak hazırlanan mısır püresi örneklerinin viskoelastik özellikleri 25 ila $50^{\circ} \mathrm{C}$ sıcaklık aralı̆̆ında bir tekstür analiz cihazı ile belirlenmiş̧tir. Yağ miktarı arttıkça, üretilen misır püresinin sert olduğu tespit edilen palm stearin içeren örnekler haricinde diğer örneklerin daha yumuşak bir yapıya sahip olduğu belirlenmiştir. Sıcaklık düştükçe, \%10-40 yağ kullanılarak üretilen pürelerin sıkılığ1 artmış ve işlenebilirliği zorlaşmıştır.

Anahtar kelimeler: mısır, püre, yağ, süt yağı, palm stearin, ayçiçeği, tekstür

${ }^{*}$ Corresponding author/Yazışmalardan sorumlu yazar;

$\bowtie$ hakanerinc@hotmail.com,

(c) (+90) 3882254005 ,

冝 (+90) 3882250112 


\section{INTRODUCTION}

In recent years, the functional and nutritional properties of foods have become important food quality parameters and requirements for the industry. Functional and nutritious foods are particularly important for the feeding of babies during the weaning period since at this critical phase of an infant's life, breast milk is mostly not adequate to meet nutritional requirements and support body growth. To compensate for this deficiency, infants need supplemental foods (Mitzner et al., 1984). Furthermore, with the growing number of working mothers, the demand for easy-to-prepare food and infant food has significantly increased. The World Health Organization (WHO) recognizes that there is a legitimate market for infant formula when a mother cannot or chooses not to breastfeed her child. However, the nutrient composition of infant formulas is often very different from that of breast milk, and some important nutrients found in the latter may be missing in the former. Therefore, particularly in cases where breastfeeding is not possible or is not sufficient alone, there is an obvious need for nutritionally balanced, energy-dense, and easily digestible weaning foods. Presently, various preparations of weaning foods are available in the market for different age groups and nutritional needs. These foods are semi-solid in nature, which makes them easy to handle for feeding infants (Hansen et al., 1981). Furthermore, considering consumer demand for natural and healthy food, it is necessary to produce foods with nutritious raw materials, rather than adding artificial ingredients.

In many developing countries, infant foods are prepared from locally available sources, mainly cereal grains, roots and tubers, which are served in a thick puree form (Sanni et al., 1999). Sweet potato is an important staple food or base material for a variety of food and industrial applications (Ravi et al., 1996). Pureeing of sweet potato (Ipomoea batatas L. Lam) is carried out on a large scale around the world (Maleki, 2001). Sweet potato is an economical and healthy food crop containing high $\beta$-carotene and carbohydrates, as well as substantial amounts of ascorbic acid and minerals (Woolfe, 1992); however, it lacks other nutrients, such as protein. Therefore, researchers have examined the ability of some additives to enhance the nutritional value of potato puree. For example, Álvarez et al. (2012) investigated the effect of soybean protein isolate on the physicochemical, functional and sensory characteristics of potato puree and found that the concentration of this isolate had a significant impact on the rheological properties of the samples. Similarly, Conforti et al. (2013) reported that whey protein concentrate, pectin, inulin, and extra virgin olive oil modified the rheological, thermal and structural properties and sensory quality of potato puree. Furthermore, in a very recent study, Miao et al. (2018) investigated the effect of the addition of soybean protein isolate, whey protein isolate, whole milk powder, and sodium caseinate on the rheological, sensory and microstructural properties of potato puree. They reported that these four proteins had a great impact on the investigated properties of potato puree.

Even though potato has certain advantages as infant food over other cereal-based foods, corn (Zea mays L.) contains more protein than potato and is cultivated in almost all countries of the world since it can grow in a wide range of climates, including tropical, sub-tropical and temperate regimes. Due to the wider use of corn compared to potato and other cereals (wheat, barley, rye), the demand for it has increased also depending on various factors, such as growing population, increased demand for processed products, growing tendency to eat healthy, increasing animal production, and development of industry. Corn has become a commonly grown agricultural product in many countries, with $90 \%$ of production being used as human food $(20 \%)$ and animal feed $(65-70 \%)$ due to the nutritional value of corn as a raw material. The remaining 8 $10 \%$ is utilized in various branches of industry (Özcan, 2009; Babaoğlu, 2005).

Corn has an average of $71.7 \%$ starch, 9.5\% protein, $9.5 \%$ fiber, and $26 \mathrm{mg} / \mathrm{kg}$ carotene. In addition, it contains B1 vitamins, pantothenic acid, folate, niacin, vitamin $\mathrm{C}$, dietary fiber, phosphorus, and magnesium. In addition, the 
dietary fiber content of corn facilitates the digestive process, prevents constipation, and reduces the risk of coronary heart disease. Corn contains vitamin $A$, which strengthens the eyes and contributes to production of blood. Furthermore, the cholesterol-lowering, antivascular, and hypoallergenic effects of corn have been reported (White and Johnson, 2003; Özcan, 2009; Rose et al., 2010; Anon, 2018).

In the literature, it has been reported that corn puree exhibited a stronger elastic characteristic (Ahmed and Ramaswamy, 2006). This is not suitable for infant formula. Therefore, various ratios of different fat sources (milk fat, sunflower, palm stearin and mixture of sunflower-palm stearin) were used in the production of corn puree, and the textural properties of the samples were determined at different temperatures to generate a new nutritional formula in this study.

\section{MATERIALS AND METHODS}

\section{Material}

In the production of corn puree, corn flour, emulsifier [mixture of mono-diglyceride (MDG), palm stearin, sunflower oil (Sunar Group, Adana, Turkey), milk powder, and milk fat (Bakkalbaşığlu Dairy Products Inc., Niğde, Turkey) were used. A mix of 37 fatty acid methyl esters (FAMEs) (C4-C24) was purchased from Supelco (Bellefonte, PA, USA). All the reagents were of analytical grade.

\section{Methods}

\section{Preparation of Corn Puree}

Corn flour, sugar, milk powder, emulsifier $(0.5 \%$ $\mathrm{MDG}$ ), and different contents of palm stearin, sunflower oil and milk fat were mixed (Table 1). $100 \mathrm{~g}$ of this mixture was transferred to a $250 \mathrm{~mL}$ beaker, and $200 \mathrm{~mL}$ of pure water heated to $80^{\circ} \mathrm{C}$ was added to the beaker. The mixture was stirred in a bain-marie at $80^{\circ} \mathrm{C}$ for 10 minutes. The textural analysis of the puree samples was carried out at different temperatures $\left(25-50^{\circ} \mathrm{C}\right)$. This allowed the determination of the effect of the components used in different amounts on the textural properties of the final product.

Table 1. Formulas used for the preparation of corn puree samples

\begin{tabular}{lcccccccc}
\hline & $\begin{array}{c}\text { Flour } \\
(\%)\end{array}$ & $\begin{array}{c}\text { Milk powder } \\
(\%)\end{array}$ & $\begin{array}{c}\text { Sugar } \\
(\%)\end{array}$ & $\begin{array}{c}\text { Emulsifier } \\
(\%)\end{array}$ & $\begin{array}{c}\text { Sunflower oil } \\
(\%)\end{array}$ & $\begin{array}{c}\text { Palm stearin } \\
(\%)\end{array}$ & $\begin{array}{c}\text { Milk fat } \\
(\%)\end{array}$ & $\begin{array}{c}\text { Mix oil } \\
(\%)\end{array}$ \\
\hline $10 S^{*}$ & 60 & 25 & 4.5 & 0.5 & 10 & - & - & - \\
$20 \mathrm{~S}$ & 60 & 25 & 4.5 & 0.5 & 20 & - & - & - \\
$30 \mathrm{~S}$ & 60 & 25 & 4.5 & 0.5 & 30 & - & - & - \\
$40 \mathrm{~S}$ & 60 & 25 & 4.5 & 0.5 & 40 & - & - & - \\
$10 \mathrm{Ps}$ & 60 & 25 & 4.5 & 0.5 & - & 10 & - & - \\
$20 \mathrm{Ps}$ & 60 & 25 & 4.5 & 0.5 & - & 20 & - & - \\
$30 \mathrm{Ps}$ & 60 & 25 & 4.5 & 0.5 & - & 30 & - & - \\
$40 \mathrm{Ps}$ & 60 & 25 & 4.5 & 0.5 & - & 40 & - & - \\
$10 \mathrm{MF}$ & 60 & 25 & 4.5 & 0.5 & - & - & 10 & - \\
$20 \mathrm{MF}$ & 60 & 25 & 4.5 & 0.5 & - & - & 20 & - \\
$30 \mathrm{MF}$ & 60 & 25 & 4.5 & 0.5 & - & - & 30 & - \\
$40 \mathrm{MF}$ & 60 & 25 & 4.5 & 0.5 & - & - & 40 & - \\
$10 \mathrm{M}$ & 60 & 25 & 4.5 & 0.5 & - & - & - & 10 \\
$20 \mathrm{M}$ & 60 & 25 & 4.5 & 0.5 & - & - & - & 20 \\
$30 \mathrm{M}$ & 60 & 25 & 4.5 & 0.5 & - & - & - & 30 \\
$40 \mathrm{M}$ & 60 & 25 & 4.5 & 0.5 & - & - & - & 40 \\
\hline
\end{tabular}

*10-40 \%fat content, S: Sunflower oil, Ps: Palm stearin, MF: Milk. fat and M: Mix oil 


\section{Analyses of raw material}

Moisture and ash content in corn flour were determined according to the International Chamber of Commerce Standard Methods No: 110/1 and 104/1 (Anon, 2002), respectively, and the protein content was determined according to the American Association for Clinical Chemistry Standard Method No. 46-12 (Anon, 2000). The corn flour was subjected to oil extraction using a Soxhlet apparatus (Gerhardt) according to the American Oil Chemist Society Official method Am 2-93 (Anon, 2003). The FAMEs of palm stearin, sunflower oil, mix oil, milk fat and emulsifier (MDG) were prepared following the method described by the International Union of Pure and Applied Chemistry (Anon, 1987). The fatty acid compositions were determined by Shimadzu GC-2010 (Japan) equipped with a DB23 capillary column $(60 \mathrm{~m} \times 0.250 \mathrm{~mm} \times 0.25 \mu \mathrm{m}$; $\mathrm{J} \& \mathrm{~W})$ and a flame ionization detector. Helium (1 $\mathrm{mL} /$ minutes) was used as the carrier gas. The split ratio was 1:80. The working temperatures of the injector, column and detector were 230, 190 and $240^{\circ} \mathrm{C}$, respectively. The FAMEs were identified by the reference standard.

\section{Analyses of puree}

The color values $\left(\mathrm{L}^{*}, \mathrm{a}^{*}\right.$ and $\left.\mathrm{b}^{*}\right)$ of the corn puree samples were measured by a Minolta CR-400 colorimeter (Konica Minolta Sensing, Osaka, Japan). The flow resistance of the samples was determined in a texture analyzer (TA-XTplus, $\mathrm{UK}$ ) using an apparatus (Figure 1) at room temperature $\left(25^{\circ} \mathrm{C}\right)$ (test speed: $1.0 \mathrm{~mm} / \mathrm{sec}$ and distance: $20 \mathrm{~mm}$ ). In this analysis, the force required for flow of the product through a certain gap $(6 \mathrm{~mm})$ was determined, and the results of the analysis were given in gram. The spreadability properties of the samples were determined at different eating temperatures $(25,30,40$ and $50^{\circ} \mathrm{C}$ ) by the 'measure force in compression' method (test speed: $3.0 \mathrm{~mm} /$ second and distance: $16 \mathrm{~mm}$ ) using the TTC Spreadability Rig $\mathrm{HDP} / \mathrm{SR}$ equipment in a texture analyzer (TAXTplus, UK).

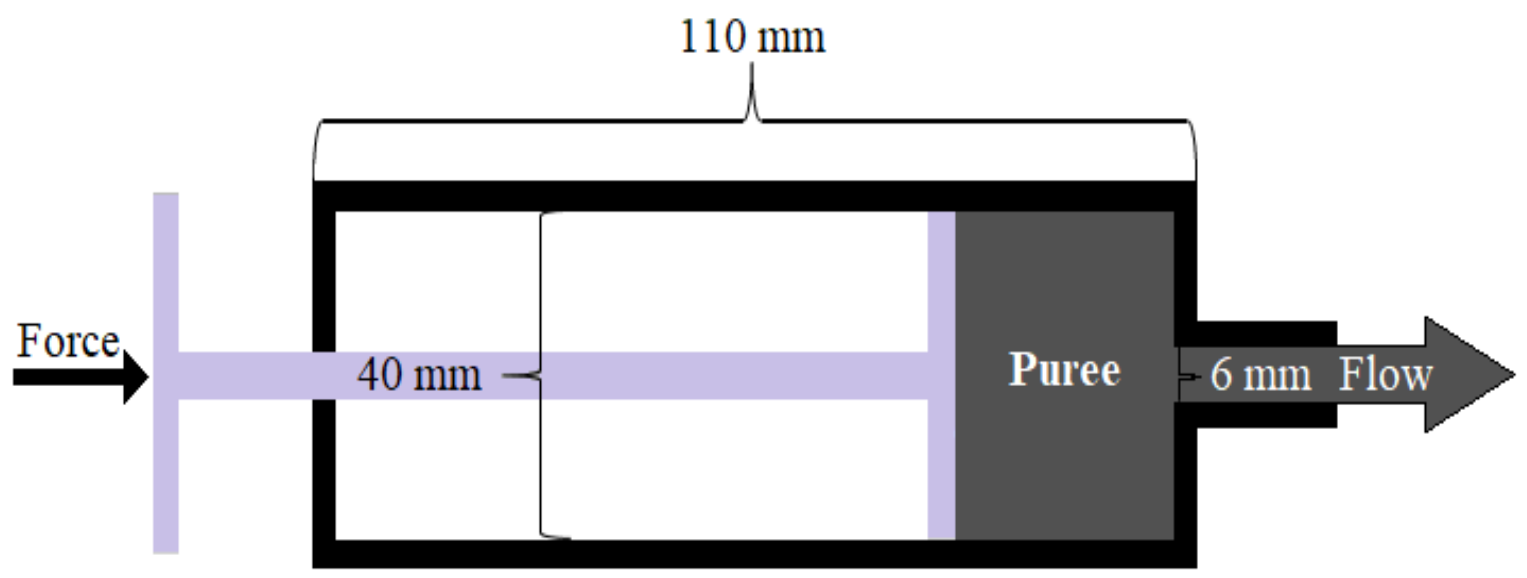

Figure 1. The apparatus used for the flow resistance analysis

\section{Statistical Analysis}

Duplicate measurements were performed for each replicate of puree production, and the results were obtained as mean values. The data was analyzed by ANOVA, and multiple comparisons of the means were undertaken using Duncan's test. Statistical analysis was performed with SPSS 15.0 for Windows Evaluation Version (SPSS Inc., Chicago, IL).

\section{RESULTS AND DISCUSSION}

The moisture, ash, oil and protein contents of the corn flour were determined as $3.50 \pm 0.035 \%$, $0.54 \pm 0.012 \%, 3.18 \pm 0.048 \%$ and $7.71 \pm 0.002 \%$, respectively. The results of the fatty acid composition analysis of the fat samples by gas chromatograph are given in Table 2. MDG used as the emulsifier contained high levels of palmitic acid $(58.94 \pm 0.485 \%)$ and stearic acid 
$(39.93 \pm 0.252 \%)$. The predominant fatty acid was found to be palmitoleic acid $(39.18 \pm 0.532 \%)$ in milk fat, palmitic acid $(63.46 \pm 0.642 \%)$ in palm stearin, and linoleic acid $(54.69 \pm 0.052 \%)$ in sunflower oil. Milk fat is usually used in puree production, but the polyunsaturated fatty acid (PUFA) content of milk fat was quite low
$(3.00 \pm 0.008 \%)$. Even though palmitic acid $(34.64 \pm 0.222 \%)$ was identified as the dominant fatty acid in the mix of palm stearin + sunflower (50:50), high amounts of oleic acid $(30.78 \pm 0.075 \%)$ and linoleic acid $(29.82 \pm 0.062 \%)$ were also determined. The PUFA content of the mixed oil was quite high $(29.85 \pm 0.062)$.

Table 2. The fatty acid composition of butter, palm stearin, sunflower oil, mix oil and emulsifier

\begin{tabular}{lrrrrr}
\hline Fatty acids (\%) & Milk fat & Palm stearin & Sunflower oil & Mix oil & \multicolumn{1}{c}{ MDG } \\
\hline Butyric acid (4:0) & $0.25 \pm 0.002$ & ND & ND & ND & ND \\
Caproic acid (6:0) & $0.12 \pm 0.001$ & ND & ND & ND & ND \\
Caprylic acid (8:0) & $1.37 \pm 0.008$ & ND & ND & ND & ND \\
Capric acid (10:0) & $0.87 \pm 0.006$ & ND & ND & ND & ND \\
Lauric acid (12:0) & $2.13 \pm 0.005$ & $0.11 \pm 0.001$ & ND & $0.06 \pm 0.001$ & ND \\
Myristic acid (14:0) & $2.75 \pm 0.003$ & $1.17 \pm 0.001$ & $0.08 \pm 0.001$ & $0.63 \pm 0.000$ & $1.01 \pm 0.004$ \\
Palmitic acid (16:0) & $12.56 \pm 0.009$ & $63.46 \pm 0.642$ & $5.81 \pm 0.012$ & $34.64 \pm 0.222$ & $58.94 \pm 0.485$ \\
Palmitoleic acid (16:1) & $39.18 \pm 0.532$ & ND & $0.12 \pm 0.022$ & $0.06 \pm 0.001$ & ND \\
Stearic acid (18:0) & $13.69 \pm 0.012$ & $4.74 \pm 0.042$ & $3.25 \pm 0.008$ & $3.99 \pm 0.042$ & $39.93 \pm 0.252$ \\
Oleic acid (18:1) & $24.32 \pm 0.022$ & $25.57 \pm 0.132$ & $35.99 \pm 0.548$ & $30.78 \pm 0.075$ & $0.07 \pm 0.001$ \\
Linoleic acid (18:2, $\omega-6)$ & $3.00 \pm 0.008$ & $4.94 \pm 0.011$ & $54.69 \pm 0.052$ & $29.82 \pm 0.062$ & $0.05 \pm 0.000$ \\
Linolenic acid (18:3, $\omega-3)$ & ND & ND & $0.06 \pm 0.001$ & $0.03 \pm 0.000$ & ND \\
SFA & $33.74 \pm 0.046$ & $69.48 \pm 0.686$ & $9.14 \pm 0.021$ & $39.32 \pm 0.265$ & $99.88 \pm 0.741$ \\
MUFA & $63.5 \pm 0.554$ & $25.57 \pm 0.132$ & $36.11 \pm 0.570$ & $30.84 \pm 0.076$ & $0.07 \pm 0.001$ \\
PUFA & $3.00 \pm 0.008$ & $4.94 \pm 0.011$ & $54.75 \pm 0.053$ & $29.85 \pm 0.062$ & $0.05 \pm 0.000$ \\
\hline ND Not Det
\end{tabular}

ND: Not Detected

SFA: Saturated Fatty Acid, MUFA: Mono Unsaturated Fatty Acid, PUFA: Poly Unsaturated Fatty Acid

Color is considered an important parameter in the marketing of food. The results of the color analysis of puree samples are given in Table 3. Since fat is bright, with the increase in the fat content, the $L^{*}$ (brightness) values of samples increased, but $\mathrm{b}^{*}$ (yellowness) values decreased (Table 3). On the other hand, a* (redness) values of samples increased with the increase in the fat content.

The composition of a food product along with its structure determines the rheology of that product (Ahmed and Ramaswamy, 2006). Fat interacts with other ingredients to develop and mold the texture, and gives feeling in the mouth, as well as an overall sensation of the lubricity of the product (Giese, 1996). The rheological and textural properties have been considered to be important analytical tools to provide a fundamental insight into the structural organization of food. Some foods, especially starches and proteins, undergo changes during processing, resulting in viscous dispersions, solutions or gels depending on temperature and concentration (Gunasekaran and $\mathrm{Ak}, 2000)$.

As shown in Figure 2, there was no change in the flow properties of the samples until the fat content reached $20 \%$. This can be explained by the fat binding capacity of starch. It has been reported that one gram of corn starch can bind 0.4 milliliters of fat (Seguchi, 1984). In products containing $30 \%$ and $40 \%$ fat (except the sample with palm stearin), increasing the fat content in the puree formulation reduced the flow resistance, and more than $20 \%$ fat concentration affected the lubricity properties. However, when palm stearin was used, unlike the other fats, the flow resistance of the corn puree increased. On the other hand, increasing the mixed fat (1:1, sunflower oil + palm stearin) increased the fluidity and flow properties of the product similar to those produced with milk fat. 
Table 3. The L*, a* and $b^{*}$ values of the corn puree samples

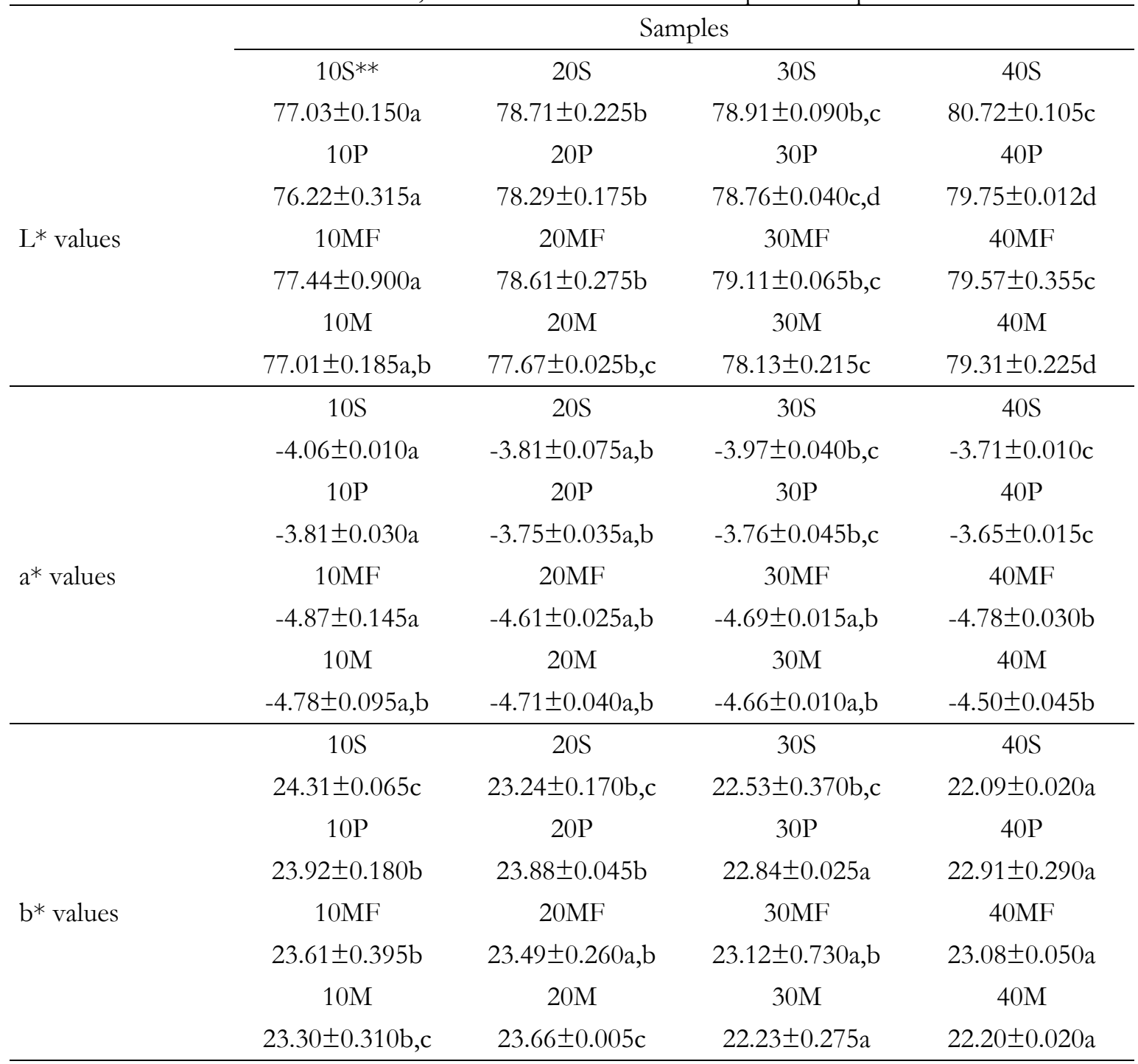

${ }^{a}$ Different superscript letters in the same row indicate a significant difference between the values at the $P<0.05$ level

**10-4 \% fat content, S: Sunflower oil, Ps: Palm stearin, MF: Milk, fat and M: Mix oilFigure 2

Puree manufacturers recommend that the product should be served warm and consumed quickly. Since puree is semi-solid, its textural properties would alter significantly during consumption depending on temperature (Woolfe, 1992).

In this study, the firmness and work of shear values of the corn purees produced using 10-40\% fat were determined at different temperatures (Table 4). As a result of the textural analysis, different properties were observed in the final product depending on the amount and type of fat used in the formulation. As the fat content increased $(40 \%)$, the corn puree became softer, except for the product containing palm stearin. Although the puree was soft with a low amount of palm stearin, it became harder as the amount of this fat was increased. As the temperature decreased, the firmness and work of shear values of the purees produced using $10-40 \%$ of oil increased. Both the $40 \mathrm{MF}$ and $40 \mathrm{M}$ purees exhibited similar viscoelastic properties $(P<0.05)$. 


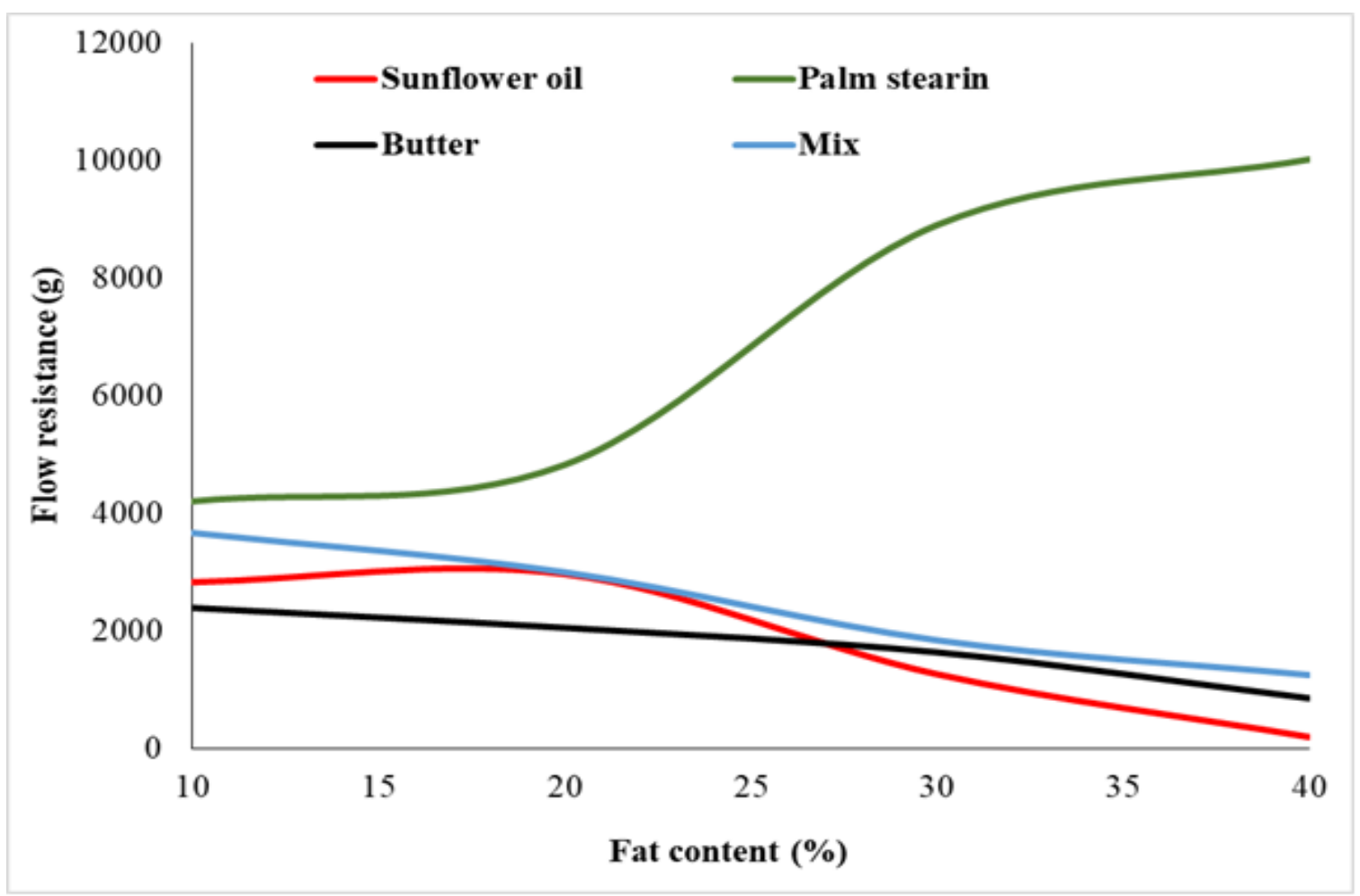

Figure 2. Flow resistance of corn puree samples

Table 4. The firmness and work of shear values of the corn puree samples

\begin{tabular}{|c|c|c|c|c|c|c|c|c|}
\hline & \multicolumn{4}{|c|}{ Firmness (g) } & \multicolumn{4}{|c|}{ Work of Shear (g.sec) } \\
\hline & $50^{\circ} \mathrm{C}$ & $40^{\circ} \mathrm{C}$ & $30^{\circ} \mathrm{C}$ & $25^{\circ} \mathrm{C}$ & $50^{\circ} \mathrm{C}$ & $40^{\circ} \mathrm{C}$ & $30^{\circ} \mathrm{C}$ & $25^{\circ} \mathrm{C}$ \\
\hline $10 S^{* *}$ & $1255^{\mathrm{e}, \mathrm{f}, \mathrm{g}}$ & $1928 \mathrm{~g}$ & $2695 \mathrm{~g}, \mathrm{~h}$ & $4415 \mathrm{~g}$ & $1958^{\mathrm{f}}$ & $2764 g$ & $3478^{\mathrm{d}, \mathrm{e}}$ & $3767 \mathrm{c}, \mathrm{d}$ \\
\hline $20 \mathrm{~S}$ & $1099 \mathrm{e}, \mathrm{f}$ & $1816 \mathrm{~g}$ & $1968^{\mathrm{e}, \mathrm{f}}$ & $3267 f$ & $1647 \mathrm{e}, \mathrm{f}$ & $2238^{f}$ & $2772^{c}$ & $3536 \mathrm{c}, \mathrm{d}$ \\
\hline $30 \mathrm{~S}$ & $630^{b, c}$ & $704^{b}$ & $760^{\mathrm{b}}$ & $801^{\mathrm{a}, \mathrm{b}}$ & $667 \mathrm{~b}$ & $771^{b}$ & $885^{\mathrm{a}, \mathrm{b}}$ & $976^{\mathrm{a}, \mathrm{b}}$ \\
\hline $40 \mathrm{~S}$ & $140^{\mathrm{a}}$ & $198^{a}$ & $229^{a}$ & $354^{a}$ & $251^{\mathrm{a}}$ & $310^{\mathrm{a}}$ & $489^{a}$ & $505^{\mathrm{a}}$ \\
\hline 10Ps & $1314^{\mathrm{f}, \mathrm{g}}$ & $1467 \mathrm{e}, \mathrm{f}$ & $1710^{\mathrm{e}}$ & $2047^{d}$ & $1476^{\mathrm{d}, \mathrm{e}}$ & $1723^{\mathrm{d}, \mathrm{e}}$ & $2530^{c}$ & $2968^{c}$ \\
\hline 20Ps & $1405^{g}$ & $1779^{\mathrm{f}, \mathrm{g}}$ & $2293 g$ & $2574^{e}$ & $1786^{\mathrm{e}, \mathrm{f}}$ & $1999 \mathrm{e}, \mathrm{f}$ & $2917 \mathrm{cdd}$ & $3632^{\mathrm{c}, \mathrm{d}}$ \\
\hline 30Ps & $1794^{\mathrm{h}}$ & $2282^{\mathrm{h}}$ & $2521^{g, h}$ & $2729 e$ & $1873^{\mathrm{f}}$ & $2950 \mathrm{~g}$ & $3753^{\mathrm{e}}$ & $4142^{\mathrm{d}}$ \\
\hline 40Ps & $2275 i$ & $2566^{\mathrm{h}}$ & $2731^{\mathrm{h}}$ & $3365^{\mathrm{f}}$ & $3201 \mathrm{~g}$ & $3852^{\mathrm{h}}$ & $4486^{\mathrm{f}}$ & $6731^{\mathrm{e}}$ \\
\hline $10 \mathrm{MF}$ & $707 \mathrm{~b}, \mathrm{c}$ & $864^{b, c, d}$ & $1117 \mathrm{~b}, \mathrm{c}$ & $1319^{\mathrm{b}, \mathrm{c}}$ & $868^{b, c}$ & $1257^{b, c, d}$ & $1351^{\mathrm{b}}$ & $1526^{\mathrm{b}}$ \\
\hline $20 \mathrm{MF}$ & $705^{b, c}$ & $844^{b, c, d}$ & $937 \mathrm{~b}, \mathrm{c}$ & $1084^{b, c}$ & $851^{b, c}$ & $1240^{b, c, d}$ & $1351^{b}$ & $1515^{b}$ \\
\hline $30 \mathrm{MF}$ & $653^{b, c}$ & $767 \mathrm{~b}, \mathrm{c}$ & $801^{b}$ & $919 \mathrm{a}, \mathrm{b}$ & $736^{\mathrm{b}}$ & $102^{b, c}$ & $1267 \mathrm{~b}$ & $1402^{\mathrm{b}}$ \\
\hline $40 \mathrm{MF}$ & $413^{\mathrm{b}}$ & $539 \mathrm{~b}$ & $726^{\mathrm{b}}$ & $865^{\mathrm{a}, \mathrm{b}}$ & $624 \mathrm{~b}$ & $888^{\mathrm{b}}$ & $1001 \mathrm{a,b}$ & $1143^{\mathrm{a}, \mathrm{b}}$ \\
\hline $10 \mathrm{M}$ & $1062^{\mathrm{e}, \mathrm{f}}$ & $1147 \mathrm{~d}, \mathrm{e}$ & $1566^{\mathrm{d}, \mathrm{e}}$ & $1889^{d}$ & $1129 \mathrm{~cd}$ & $1414 \mathrm{c}, \mathrm{d}$ & $2212^{c}$ & $2704^{c}$ \\
\hline $20 \mathrm{M}$ & $1001^{\mathrm{d}, \mathrm{e}}$ & $1124 \mathrm{c}, \mathrm{d}, \mathrm{e}$ & $1543^{\mathrm{d}, \mathrm{e}}$ & $1881^{d}$ & $1126^{\mathrm{c}, \mathrm{d}}$ & $1412^{\mathrm{c}, \mathrm{d}}$ & $2162^{c}$ & $2525^{c}$ \\
\hline $30 \mathrm{M}$ & $764 c, d$ & $844^{b, c, d}$ & $1279 \mathrm{~cd}$ & $1517 \mathrm{cdd}$ & $906^{b, c}$ & $1230^{b, c, d}$ & $1514 \mathrm{~b}$ & $1605^{b}$ \\
\hline $40 \mathrm{M}$ & $460^{\mathrm{b}}$ & $553^{\mathrm{b}}$ & $756^{\mathrm{b}}$ & $901^{\mathrm{a}, \mathrm{b}}$ & $657^{\mathrm{b}}$ & $950^{\mathrm{b}, \mathrm{c}}$ & $1104^{a, b}$ & $1200^{a, b}$ \\
\hline
\end{tabular}


The fat concentration was directly related to the fatty acid composition, and the physical properties of the oil (solid-liquid) affected the fluidity of the final product. Thus, the results of the current study indicate that sunflower oil produces a softer corn puree than palm stearin and milk fat. Another important finding was that purees produced with a mixture of suitable oils result in similar textural properties similar to those of milk fat puree.

In the literature, it has been reported that when the fat concentration in biscuit dough formula is reduced, the resultant dough samples become harder (Erinç, 2011). In another study conducted by Ertaş and Karabaş (1996), sunflower oil was used in sausage production, and the sausages were found to be softer as the sunflower oil content increased. In a similar study by Jacob and Leelavathi (2007), who used different oils in biscuit formulas, biscuit dough produced with hydrogenated oil was harder than the dough prepared with sunflower oil. Babji et al. (1998) used different oils (palm stearin, commercial oils, and animal fat) in hamburger formulas and reported that with the increased fat content, the hamburger dough had a harder texture.

\section{CONCLUSION}

Different results were obtained from the final products depending on the amount and type of fat used in the corn puree formula. However, all corn purees exhibited viscoelastic behavior. The textural properties of the corn purees containing up to $20 \%$ fat were not greatly affected. In products with more than $20 \%$ fat content, the textural characteristics changed depending on the type of fat. When unsaturated fatty acid containing fats were used, softer corn puree production was achieved from all samples. On the other hand, as the fat content increased, the corn puree became softer, except for the palm stearincontaining product, which formed a rather rigid structure.

\section{REFERENCES}

Ahmed, J. and Ramaswamy, H. S. (2006). Viscoelastic and thermal characteristics of vegetable puree-based baby foods. J Food Process Eng, 29: 219-233.

Álvarez, M. D., Fernández, C., Olivares, M. D., Canet, W. (2012). A rheological characterisation of mashed potatoes enriched with soy protein isolate. Food Chem, 133(4): 1274-1282.

Anon. (2000). Approved Methods of American Association of Cereal Chemists (AACC). The Association: St. Paul, Mn.

Anon. (2002). Standard Methods of International Association for Cereal Science and Technology (ICC). Vienna, Austria.

Anon. (2003). Official methods and recommended practices of the American Oil Chemists' Society, Method Am 2-93, AOCS Press, Champaign, IL (USA).

Anon. (2018). How to cook corn porridge for baby feeding: recipes for cooking on water and milk. for a child under 1 year, http://childrensis.com/en/pages/798697 (last accessed 10.10.2018).

Babaoğlu, M. (2005). Misır ve Tarmı, Trakya Tarımsal Araştırma Enstitüsü Müdürlüğü Edirne, Turkey.

Babji, A. S., Alina, A. R., Seri Chempaka, M. Y., Sharmini, T., Basker, R., Yap, S. L. (1998). Replacement of animal fat with fractionated and partially hydrogenated palm oil in beef burgers. Int J Food Sci Nutr, 49(5): 327-332.

Conforti, P. A., Lupano, C. E., Yamul, D. K. (2013). Rheological, thermal and sensory properties of whey protein concentrate/pectinfortified mashed potatoes made from dehydrated flakes. Int J Food Sci Technol, 48(5): 1035-1040.

Erinç, H. (2011). Bitkisel artıklardan farklı boyutlarda lif üretimi ve düşük yağlı ürünlerde kullanımı. PhD thesis, Ankara University, Turkey.

Ertaş, A. H. and Karabaş, G. (1996). Ayçiçek Yağ1 ile Frankfurter Tipi Sosis Üretimi Üzerinde Araştırma. Turk J Agric For, 22: 235-240.

Giese, J. (1996). Fats, oils and fat replacers. Food Technol, 50: 48-83. 
Gunasekaran, S. and Ak, M. M. (2000). Dynamic oscillatory shear testing of foods-selected applications. Trends in Food Sci Tech, 11: 115-127.

Hansen, L. P., Hosek, R., Callan, M., Jones, F. T. (1981). The development of high-protein rice flour for early childhood feeding. Food Technol, 35: $38-42$.

Jacob, J. and Leelavathi, K. (2007). Effect of fattype on cookie dough and cookie quality. J Food Eng, 79: 299-305.

Maleki, S. (2001). The big eight food allergens. Dietitian's Edge, 2: 57-60.

Miao, W., Hatab, S., Gu, Y., Wang, L., Xu, X., Pan, S. (2018). Rheological, sensory, and microstructural properties of fresh and frozen/thawed mashed potatoes enriched with different proteins, CyTA - J Food, 16(1): 113-121.

Mitzner, K., Scrimshav, N., Morgan, R. (Eds.) (1984). Improving the nutritional status of children during the weaning period. Cambridge, MA, USA: HOVIPREP (Home- and Village-Prepared Weaning Foods) Publications Massachussetts Institute of Technology.

Özcan, S. (2009). Modern Dünyanın Vazgeçilmez Bitkisi Mısır: Genetiği Değiştirilmiş (Transgenik) Misırin Tarımsal Üretime Katkıs1, Türk Bilimsel Derlemeler Dergisi, 2(2): 01-34.
Ravi, V., Aked, J., Balagopalan, C. (1996). Review on tropical root and tuber crops. I. Storage methods and quality changes. Crit Rev Food Sci Nutr, 36: 661-709.

Rose, D. J., Inglett., G. E., Liu, S. X. (2010). Utilisation of corn (Zea mays) bran and corn fiber in the production of food components. J Sci Food Agric, 90(6): 915-24.

Sanni, A. I., Onilude, A. A., Ibidapo, T. (1999). Biochemical composition of infant weaning food fabricated from fermented blends of cereal and soybean. Food Chem, 65: 35-39.

Seguchi, M. (1984). Oil-binding capacity of prime starch chlorinated wheat flour. Cereal Chem, 61: 241-243.

White, P. J. and Johnsan, L. A. (2003). Corn Chemistry and Technology, American Association of Cereal Chemists, St. Paul, MN, US.

Woolfe, J. A. (1992). Sweet potato: An untapped food resource. Cambridge, UK: Cambridge University Press, p. 642. 